\title{
BIODEGRADABLE BILIARY STENTS: A NEW APPROACH FOR THE MANAGEMENT OF HEPATICOJEJUNOSTOMY STRICTURES FOLLOWING BILE DUCT INJURY. PROSPECTIVE STUDY
}

\author{
Stent biliar biodegradável: uma nova abordagem para as estenoses hepaticojejunais após lesão do ducto biliar. Estudo \\ prospectivo
}

Mariano E. GIMÉNEZ, Mariano PALERMO, Eduardo HOUGHTON, Pablo ACQUAFRESCA, Caetano FINGER, Juan M. VERDE, Jorge Cardoso CÚNEO

From the Docencia, Asistencia e Investigación en Cirugía Invasiva Mínima DAICIM Foundation, Buenos Aires, Argentina

\footnotetext{
HEADINGS - Hepaticojejunostomy stricture. Biodegradable stent. Bile duct injury.
}

ABSTRACT - Background: Once a biliary injury has occurred, repair is done by a hepaticojejunostomy. The most common procedure is to perform a dilatation with balloon with a success of $70 \%$. Success rates range using biodegradable stents is from $85 \%$ to $95 \%$. Biodegradable biliary stents should change the treatment of this complication. Aim: To investigate the use of biodegradable stents in a group of patients with hepaticojejunonostomy strictures. Methods: In a prospective study 16 biodegradable stents were placed in 13 patients with hepaticojejunostomy strictures secondary to bile duct repair of a biliary surgical injury. Average age was 38.7 years (23-67), nine were female and four male. All cases had a percutaneous drainage before at the time of biodegradable stent placement. Results: In one case, temporary haemobilia was present requiring blood transfusion. In another, pain after stent placement required intravenous medication. In the other 11 patients, hospital discharge was the next morning following stent placement. During the patient's follow-up, none presented symptoms during the first nine months. One patient presented significant alkaline phosphatase elevation and stricture recurrence was confirmed. One case had recurrence of cholangitis 11 months after the stent placement. $84.6 \%$ continued asymptomatic with a mean follow-up of 20 months. Conclusion: The placement of biodegradable stents is a safe and feasible technique. Was not observed strictures caused by the stent or its degradation. It could substitute balloon dilation in strictures of hepaticojejunostomy.
RESUMO - Racional: Uma vez que lesão biliar ocorreu, o reparo é feito por hepaticojejunostomia. O procedimento mais comum é efetuar dilatação com balão com sucesso de $70 \%$. As taxas de sucesso utilizando stents biodegradáveis é de $85 \%$ a $95 \%$. Stents biliares biodegradáveis devem mudar o tratamento desta complicação. Objetivo: Investigar o uso de stents biodegradáveis em um grupo de pacientes com estenose hepaticojejunal Métodos: Em estudo prospectivo 16 stents biodegradáveis foram colocados em 13 pacientes com estenose de hepaticojejunostomia secundárias usados para reparação do ductos biliares de lesão cirúrgica. A média de idade foi de 38,7 anos (23-67), nove pacientes eram homens e quatro mulheres. Todos os casos tiveram drenagem percutânea antes do momento da colocação de stent biodegradável. Resultados: Em um caso, haemobilia temporária estava presente com necessidade de transfusão de sangue. Em outro, dor após a colocação do stent necessitou de medicação intravenosa. Nos outros 11 pacientes, alta hospitalar foi na manhã seguinte após o procedimento. Durante o seguimento, nenhum apresentou sintomas durante os primeiros nove meses. Um paciente apresentou significativa elevação da fosfatase alcalina por recidiva da estenose. Um caso teve recorrência de colangite 11 meses após a colocação do stent. Continuaram assintomáticos $84,6 \%$ com média de acompanhamento de 20 meses. Conclusão: A colocação de stents biodegradáveis é técnica segura e viável. Não foram observadas restrições causadas pelo stent ou pela sua degradação. Stent pode substituir dilatação com balão na estenose de hepaticojejunostomia.
DESCRITORES: Hepaticojejunostomia estenose. Stent biodegradável. Lesão do ducto biliar.

\section{INTRODUCTION}

$\mathrm{O}$ nce a biliary injury has occurred, especially in the case of complex lesions, repair is done by a hepaticojejunostomy. When a stricture of the anastomosis occurs, the most common procedure is to perform a dilatation with balloon with a success of $70 \%$. Using biodegradable stents, success rate of the procedure in tertiary centers goes from $85 \%$ to $95 \% \%^{7,15,29}$. When a hepatopancreatobiliary surgeon does not do the repair, results are alarmingly compromised $4,7,15,29$.

Strictures of a hepaticojejunostomy present with clinical signs of repeated cholangitis, with or without jaundice. Complementary laboratory studies report elevation of alkaline phosphatase and leukocytes. Ultrasound identifies intrahepatic dilatation of the bile duct in $50 \%$ of the cases and cholangioresonance identifies the stricture of the anastomosis. The presence of pneumobilia and of an intestinal loop in the area may confound the diagnosis, especially in non-dilated bile ducts.

In many of these patients, treatment of the cholangitis consists of antibiotic therapy and percutaneous drainage of the bile duct, confirming also the diagnosis of a 
stricture. Once the infection is under control, a percutaneous dilatation of the stricture can be performed with high-pressure balloon, unless there are severe construction deficiencies in the previous biliodigestive anastomosis. Long-term success rates with this technique range between $45 \%$ and $71 \%$, according to different series $3,18,23$.

Recurrence rates with this technique are approximately $40 \%$ and as successive dilations at around four months shall be needed, it is necessary to find other minimally invasive treatments for these patients.

The aim of the present study was to investigate the use of biodegradable stents in a group of patients with hepaticojejunostomy strictures.

\section{METHODS}

In a prospective study carried out in a specialized reference center, since March 2011, 16 biodegradable stents were placed using the percutaneous route in 13 patients with hepaticojejunostomy strictures secondary to bile duct repair of a biliary surgical injury (Table 1).

Average age in the series was 38.7 years (23-67), nine patients were female. In nine patients, the hepaticojejunostomy stricture was treated with a high-pressure balloon (three sessions with 8 to $10 \mathrm{~mm}$ diameter balloons at 6 atmosphere pressure for $3 \mathrm{~min}$ ) and in four patients, with failure of the balloon dilatation, with prolonged dilatation with 5 to 6 percutaneous plastic stents during nine to 12 months. In two patients a stent was placed, as the balloon dilatation did not seem to be effective after the second session.

In four cases stents were placed without previous percutaneous dilatation.

All cases had a percutaneous drainage at the time of stent placement. One presented an intrahepatic lithiasis located proximal to the stent. Three patients had bilateral drainage, six only from the right hepatic duct and four from the left one. No patient presented cholangitis at the moment of stent placement.

During that session and before stent placement, the stricture was dilated with a $8 \mathrm{~mm}$ diameter high-pressure balloon. Following stent placement a supra-stent external drainage was placed and removed next morning, previous to hospital discharge.

The stent (ELLA-CS, s.r.o., Hradec Kralove, Czech Republic) is a biodegradable stent made of polydioxanone, that is a semicrystalline, biodegradable polymer of the polyester family ${ }^{7}$. The size used in all cases was $10 \mathrm{~mm}$ in diameter by $40 \mathrm{~mm}$ long. The stent is radiolucent with two radiopaque markers at both stent ends. Prior to placement it is mounted on a 15 French introducer (Figure 1).

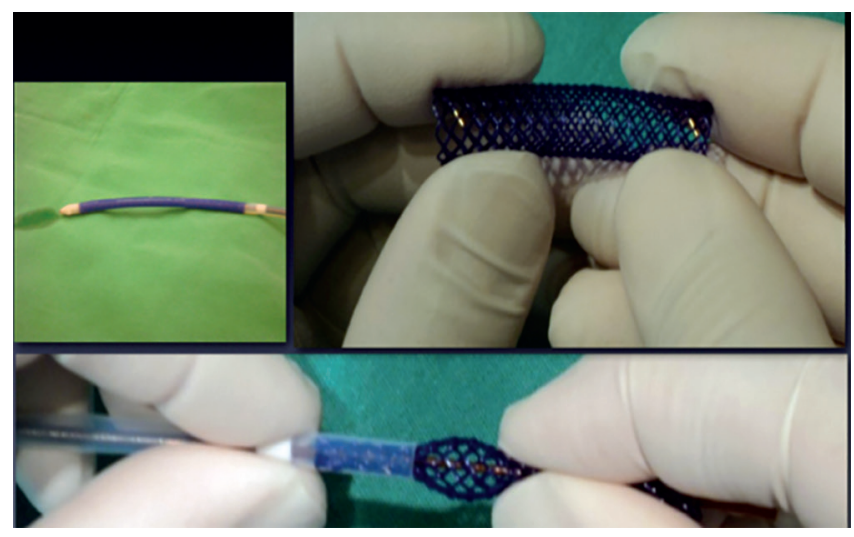

FIGURE 1 - Biodegradable stent mounting on the introducer: radiopaque markers on both stent edges

Patient's follow-up was 18 to 24 months. Follow-up was carried out by clinical examinations, laboratory studies and images (CT-Scan or MRI).

Clinical success was defined as absence of repeated cholangitis or alkaline phosphatase elevation during patient follow-up.

The procedurewas performed before the patient's signature of the consent and information form and the approval of the bioethics committee.

TABLE 1 - Analysis of the 13 treated cases

\begin{tabular}{|c|c|c|c|c|c|c|c|c|c|}
\hline$n$ & Gender & Age & Stricture & $\begin{array}{l}\text { Initial treatment of } \\
\text { cholangitis }\end{array}$ & $\begin{array}{l}\text { Initial treatment of } \\
\text { stricture }\end{array}$ & Re-drainage & Stent & Result & $\begin{array}{l}\text { Follow up } \\
\text { (in months) }\end{array}$ \\
\hline 1 & $\mathrm{~F}$ & 23 & Hepaticojejunostomy & $\mathrm{PBD}+\mathrm{atb}$ & $\begin{array}{c}\text { Balloon/sustained } \\
\text { dilation }\end{array}$ & Yes & 1 & Asymptomatic & 24 \\
\hline 2 & $\mathrm{~F}$ & 45 & Hepaticojejunostomy & $\mathrm{PBD}+\mathrm{atb}$ & Balloon & Yes & 1 & Asymptomatic & 24 \\
\hline 3 & $\mathrm{~F}$ & 39 & Hepaticojejunostomy & $\mathrm{PBD}+\mathrm{atb}$ & Balloon & No & 1 & Asymptomatic & 23 \\
\hline 4 & M & 49 & Hepaticojejunostomy & $\mathrm{PBD}+\mathrm{atb}$ & Balloon & Yes & 1 & Asymptomatic & 23 \\
\hline 5 & M & 26 & Hepaticojejunostomy & PBD bilateral + atb & $\begin{array}{c}\text { Balloon/sustained } \\
\text { dilation }\end{array}$ & Yes & 2 & Asymptomatic & 23 \\
\hline 6 & $\mathrm{~F}$ & 42 & Hepaticojejunostomy & $\mathrm{PBD}+\mathrm{atb}$ & $\begin{array}{l}\text { Balloon/sustained } \\
\text { dilaton }\end{array}$ & Yes & 1 & Asymptomatic & 22 \\
\hline 7 & M & 38 & Hepaticojejunostomy & $\mathrm{PBD}+\mathrm{atb}$ & Balloon & No & 1 & Asymptomatic & 21 \\
\hline 8 & $\mathrm{~F}$ & 27 & Hepaticojejunostomy & PBD bilateral + atb & No treatment & No & 2 & Redrainage & $11 / 20^{*}$ \\
\hline 9 & $\mathrm{~F}$ & 31 & Hepaticojejunostomy & $\mathrm{PBD}+\mathrm{atb}$ & No treatment & No & 1 & Asymptomatic & 19 \\
\hline 10 & $\mathrm{~F}$ & 32 & Hepaticojejunostomy & $\mathrm{PBD}+\mathrm{atb}$ & $\begin{array}{c}\text { Balloon/sustained } \\
\text { dilation }\end{array}$ & Yes & 1 & $\begin{array}{c}\text { Redrainage / } \\
\text { surgery }\end{array}$ & $12 / 19 *$ \\
\hline 11 & M & 67 & Hepaticojejunostomy & $\mathrm{PBD}+\mathrm{atb}$ & No treatment & No & 1 & Asymptomatic & 19 \\
\hline 12 & $\mathrm{~F}$ & 58 & Hepaticojejunostomy & PBD bilateral + atb & Balloon & Yes & 2 & Asymptomatic & 18 \\
\hline 13 & $\mathrm{~F}$ & 27 & Hepaticojejunostomy & $\mathrm{PBD}+$ atb & No treatment & No & 1 & Asymptomatic & 18 \\
\hline
\end{tabular}

$\mathrm{F}=$ female; $\mathrm{M}=$ male; $\mathrm{PBD}=$ percutaneous biliary drainage; $\mathrm{Atb}=$ antibiotic therapy; balloon=dilatation with high-pressure balloon; sustained dilatation=dilation sustained with five to six $8 \mathrm{Fr}$. plastic stents during 9 to 12 months; ${ }^{*}=$ time stent placement and re-drainage/total follow- up 
RESULTS

Sixteen stents were placed in 13 patients (Figure 2).
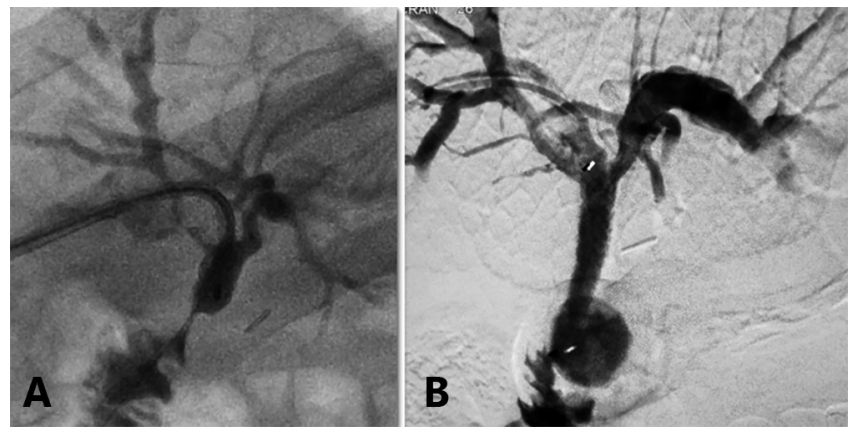

FIGURE 2 - A) Hepaticojejunostomy stricture; B) biodegradable stent placed with identification of radiopaque markers

In three cases two stents were placed, one in a stricture of a bilateral hepaticojejunostomy (Figure 3) and two in stricture of the hepaticojejunostomy with fibrosis of both hepatic ducts (Figure 4). Technical implantation of the stent was successful in all patients.
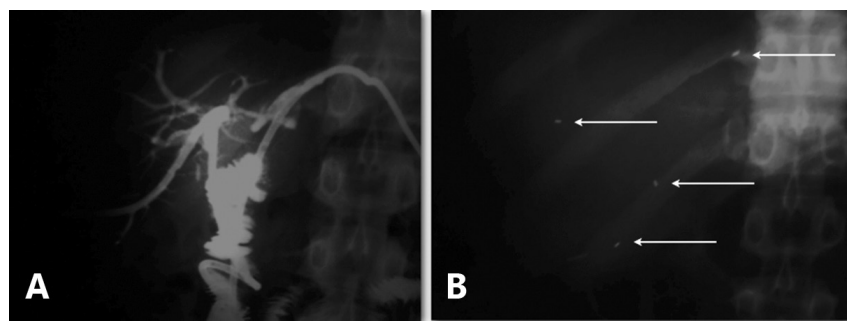

FIGURE 3 - A) Stricture of the hepaticojejunostomy drained bilaterally; B) plain X-ray of the same patient with identification of the radiopaque markers of both biodegradable stents placed
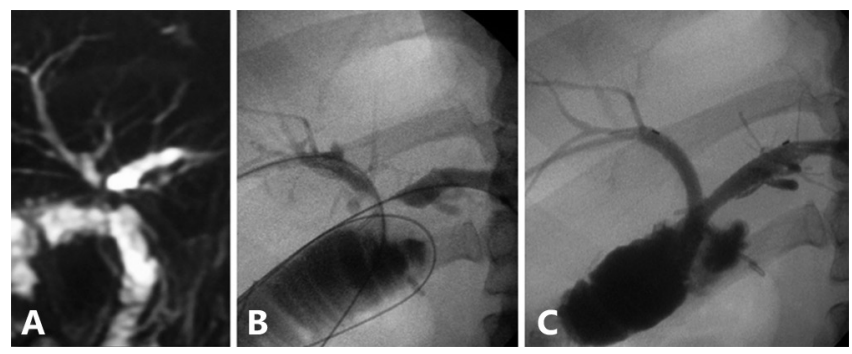

FIGURE 4 - MRI of a hepaticojejunostomy stricture involving both hepatic ducts: A) bilateral percutaneous drainage; $B$ and $C)$ placement of two biodegradable stents

In one case, temporary haemobilia was present in the suprastent drainage, requiring blood transfusion, delaying hospital discharge for $24 \mathrm{~h}$. In another case, pain after stent placement (in one of the bilateral cases) required intravenous medication and delayed the discharge for $72 \mathrm{~h}$. In the rest of cases, 11 patients, hospital discharge was the next morning following stent placement. All patients were discharged without drainage.

During the patient's follow-up, none presented symptoms during the first nine months. In all cases, alkaline phosphatase decreased, reaching normal values in six.

Stent presence, positioning and degradation were studied by images. Sequential CT-Scans were performed in two patients, $\mathrm{MRI}$ in five, and both studies in five. In one patient, no images were done after stent placement because they where asymptomatic and with unremarkable after stent placement (Table 2). No complications were observed related to stent degradation.
TABLE 2 - Degradation time (by CT/MRI scan)

\begin{tabular}{l|c|c|c|c|c|c|c|c|}
\hline Follow -up* & 0 & 4 & 8 & 12 & 16 & 20 & 24 & 28 \\
\hline Stent visualization & $12 / 12$ & $5 / 5$ & $3 / 3$ & $12 / 12$ & $9 / 10$ & $3 / 8$ & $1 / 3$ & $0 / 1$ \\
\hline$\%$ & $100 \%$ & $100 \%$ & $100 \%$ & $100 \%$ & $90 \%$ & $37,5 \%$ & $33 \%$ & $0 \%$ \\
\hline * in weeks
\end{tabular}

One patient nine months after stent placement, presented an episode of cholangitis, with a minor elevation of the alkaline phosphatase, without dilatation of the intrahepatic bile duct. MRI was unable to diagnose recurrence of the stricture and a percutaneous drainage was placed. The transparietohepatic cholangiography showed absence of a stricture in the anastomosis, with good bilateral passage of contrast to the jejunum (Figure 5). The drainage was carried out and a short jejunal Roux limb "sump syndrome following hepaticojejunonostomy" was identified, a condition overlooked during the initial treatment of the stricture, and medical treatment was indicated.

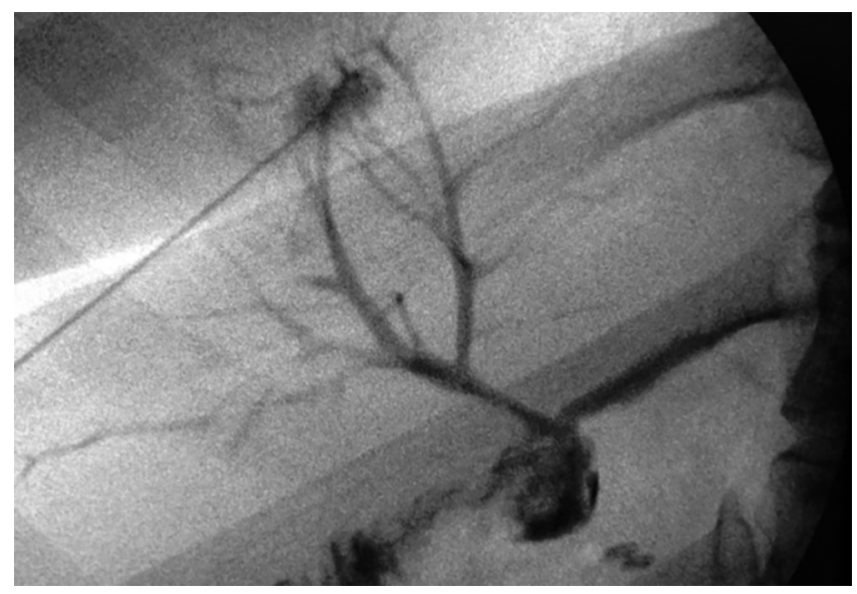

FIGURE 5 - Patient 8 with symptom recurrence at month 9, with a monthly episode of cholangitis. Non-conclusive MRI. Transparietohepatic cholangiography was done, showing absence of stricture; good contrast passage to the jejunum

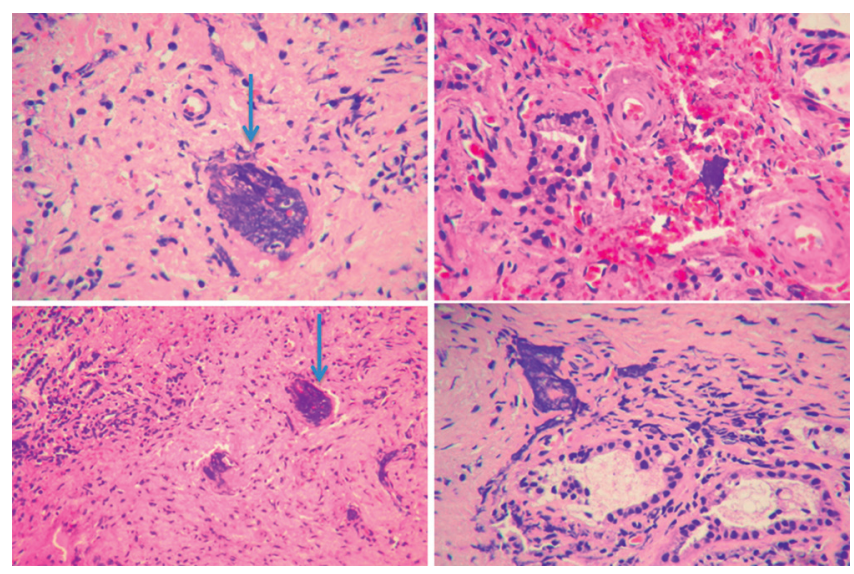

FIGURE 6 - Patient 10 with symptoms recurrence at month 11. Re-drainage and re-operation with surgical extraction of the involved area and redo-hepaticojejunostomy. Anatomopathological report of the bile duct: "Basophilic amorphus material of synthetic origin observed in the biliary mucosa. No significant inflammatory reaction"

Patient number 10 presented a significant alkaline phosphatase elevation eight months after stent placement, with repeated cholangitis by month 11 , re-drainage and antibiotic therapy were indicated. Stricture recurrence was confirmed; a surgical 
excision of the area involved and a new hepaticojejunostomy were carried out. The pathology report, indicated presence of basophilic amorphus material of synthetic origin in the biliary mucosa without significant inflammatory reaction (Figure 6).

Eleven patients (84.6\%) continued asymptomatic with a mean follow-up of 20 months.

\section{DISCUSSION}

The initial use of biodegradable stents was in the digestive tract, its first indications were for benign esophageal ${ }^{2,25,29}$ and colonic ${ }^{9,21}$ strictures.

The first publications referring to the possible use in the bile duct date back to mid 2000's $\mathrm{s}^{14,16}$. Later, several animal studies $^{8,11,12,13}$ confirmed their feasibility and absence of deleterious effects in their utilization or degradation; all this allowed these stents to be subsequently used in human beings. Recently, some isolated clinical cases in benign strictures and as splints in biliodigestive anastomosis have been reported ${ }^{19,22}$. This is the first series and follow-up of patients with benign biliary strictures secondary a hepaticojejunostomy by bile duct injury treated with biodegradable stents.

It is generally accepted that in hepaticojejunostomy strictures, unless the existence of severe construction deficiencies, the initial treatment is percutaneous drainage and dilatation with a high pressure balloon ${ }^{3,18,23}$. When ineffective or when the patient presents repeated cholangitis, the treatment to follow next is still matter of controversy. A redo-hepaticojejunostomy, a liver excision or, in selected cases, even a liver transplantation ${ }^{2}$ may be carried out according to the case.

For a couple of years and as another treatment option, we have been carrying out in our Center and in an unpublished series, sustained percutaneous dilatation with multiple plastic stents for nine to 12 months. Even though it is a treatment with long-term patency results of $80 \% 5,6$, it is technically complex - both placement and removal of the catheters - and when done by a percutaneous approach, it requires one or two external percutaneous drainages for several months. Therefore, biodegradable stents could allow sustained dilatation, without the long-term complications of catheters or metallic stents.

The stent used in this study is a biodegradable stent manufactured from a commercially available polydioxanone absorbable surgical suture. Polydioxanone is a semicrystalline, biodegradable polymer belonging to the polyester family. The stent is radiolucent with radiopaque markers at both proximal and distal ends ${ }^{7}$. Theoretically, this biodegradable stent allows long-term dilatation without the need for removal. It is braided from a monofilament of specially treated polydioxanone, a reabsorbable suture and implant material used for over 20 years ${ }^{24}$.

Degradation occurs by hydrolysis ${ }^{27}$. The monofilament loses $50 \%$ of its breaking strength after three weeks and is absorbed within six months ${ }^{17}$; a reduced $\mathrm{pH}$ accelerates hydrolysis.

The degradation product, glyoxylic acid, is the primary precursor of oxalic acid and is an intermediate in the conversion of glycolic acid to glycine. None of the degradation products or intermediates is harmful. The degradation process occurs in two stages. The first involves amorphous regions of the matrix and the second involves the crystalline areas of the polymer. Because of the fact that mechanical and physical properties largely depend on the presence of the crystalline areas, the effect of the degradation is not linear ${ }^{26}$.

Regarding degradation time, an in-vitro study performed by ELLA-CS showed that in a saline solution buffered with sodium phosphate $(\mathrm{pH} 7)$ at a temperature of $37^{\circ} \mathrm{C}$, the radial strength was around initial values for the first five weeks. At week 7 , the radial strength was about two thirds and at week 9 about one half of the initial strength ${ }^{26}$. In our series, imaging studies after stent placement show presence of the stent in all the patients studied up to week $12,37.5 \%$ up to week 20 , and no stent was seen at week 28 (Table 2).

There are different kinds of publications on biodegradable stents used in the bile duct, most of them are experimental studies in animals (Table 3 ).

TABLE 3 - Publications on type of biodegradable stents used in the bile duct

\begin{tabular}{|c|c|c|}
\hline Reference & Type of stent & Specifications \\
\hline Meng $2006^{16}$ & $\begin{array}{l}\text { Self expandable } \\
\text { helical stent }\end{array}$ & Poly-I-lactic acid \\
\hline $\begin{array}{l}\text { Laukkarinen } \\
2007^{13,14}\end{array}$ & $\begin{array}{l}\text { Self expandable } \\
\text { stent }\end{array}$ & $\begin{array}{l}\text { Melt spinning of } 96 \mathrm{~L} / 4 \mathrm{D} \\
\text { biodegradable polylactide } \\
\text { blended with barium sulfate. }\end{array}$ \\
\hline Tashiro $2009^{28}$ & $\begin{array}{l}\text { Non expandable } \\
\text { stent }\end{array}$ & $\begin{array}{l}\text { Copolymerization of L-lactide } \\
\text { and E-caprolactone }\end{array}$ \\
\hline $\begin{array}{l}\text { Yamamoto } \\
2011^{30}\end{array}$ & $\begin{array}{c}\text { Balloon } \\
\text { expandable Z } \\
\text { stent }\end{array}$ & Poly-I-lactic acid \\
\hline Itoi $2011^{8}$ & $\begin{array}{l}\text { Self expandable } \\
\text { stent }\end{array}$ & $\begin{array}{l}\text { Polyglecaprone suture 4-0 } \\
\text { wire. (hand-made) }\end{array}$ \\
\hline Giménez 2013* & $\begin{array}{l}\text { Self expandable } \\
\text { stent }\end{array}$ & $\begin{array}{c}\text { Polydioxanone, } \\
\text { biodegradable polymer of } \\
\text { the polyester family }\end{array}$ \\
\hline
\end{tabular}

*This series

As to the indications for biodegradable stents in the bile duct, besides those described in the present series, we can mention splinting of surgical biliodigestive anastomosis. According to studies performed by Laukkarinen et al. ${ }^{13,14,20}$ in hepaticojejunostomy in non-dilated ducts, at 18 month follow-up, biodegradable stents were easier to insert, nontoxic, disappear safely from the anastomosis and may be associated with a larger and better drainage of the anastomosis. Another indication mentioned by these researchers in a study carried out in experimental animals ${ }^{12}$ is stent placement in trans-cystic-duct bile leakage or lateral injury of the bile duct. They observed a reduction in the drain output and duration of bile leakage. Finally, these stents may be used in benign partial strictures of the bile duct without biliodigestive diversions. Theoretically this would avoid a surgical repair, but the possible cholangitis or pancreatitis due to stent degradation are yet to be established.

During the follow-up, two patients presented symptoms of cholangitis requiring re-drainage. In one, when a new drainage was placed, both hepatic ducts and anastomosis were patent (Figure 5), implying that apparently the stents had been effective, but a sump syndrome for the hepaticojejunostomy reconstruction was observed, causing reflux of intestinal fluid to the anastomosis. This condition together with a bilateral stricture had been overlooked during the first procedure. In these cases, cholangitis was not accompanied by severe fluctuations of alkaline phosphatase.

In the other patient with a repeated cholangitis, a re-drainge was performed confirming the stricture of the anastomosis and carrying out a partial excision of the stricture biliary area and a re-hepaticojejunostomy. The pathology report (Figure 6) indicated stent inclusion in the biliary mucosa with little inflammatory components. In an experimental study in animals Yamamoto ${ }^{30}$ observed that after placement of a biodegradable stent in the bile duct, there was a moderate endothelial proliferation at month 3, but mild or absent at month 9 . On the other hand, the author observed embedding of the stent in two of the three cases at month 9, such as we observed in the case of the excision.

At present, fully covered metallicstents are used endoscopically, the idea is to remove them later and induce sustained dilatation during that period. In an experimental study by Bakhru et al. ${ }^{1}$, the biliary mucosa was analyzed after placement of fully-covered stents, during three months. At the moment of stent removal, there was slight endothelial proliferation, which progressed to a moderate chronic inflammation one month after removal. 
These events did not represent a severe inflammatory or fibrotic duct injury. Likewise, in a retrospective multicentre analysis ${ }^{10}$, covered stent were removed in the 37 cases tested. Three patients presented secondary strictures at the distal stent margin of oversized intra-ductal stents and another stricture at the proximal stent margin of an oversized trans-papillary stent. Nevertheless, percutaneous and endoscopic approaches and specially removal of covered stents in hepaticojejunostomy is a complex technique, not exempt of a possible failure. In high strictures, the placement of a covered stent could also occlude secondary biliary branches, causing cholangitis.

The results in our series prompt us to consider changing the management algorithm of this condition, and therefore, in case of strictures of biliodigestive anastomosis - without severe construction deficiencies - the treatment option shall be drainage with placement of a biodegradable stent, thus replacing the treatment presently used which is balloon dilation.

Technical matters are yet to be resolved, such as - as in this series - dilatation previous to stent placement; improvement of the introducer system for stent mounting and reduction of its diameter. Finally, it will be necessary to have a long-term follow-up to determine the true benefit of this treatment.

\section{CONCLUSIONS}

The placement of biodegradable stents is a safe and feasible technique. We did not observed strictures caused by the biodegradable stent or its degradation. A long-term follow-up is necessary to establish the actual patency of the stricture. It could eventually substitute balloon dilation in the treatment of strictures of hepaticojejunostomy, changing radically the way of treat this complex patients.

\section{REFERENCES}

1. Bakhru MR, Foley PL, Gatesman J, Schmitt T, Moskaluk CA, Kahaleh M Fully covered self-expanding metal stents placed temporarily in the bile duct: safety profile and histologic classification in a porcine model. BMC Gastroenterol. 2011 Jun 20;11:76.

2. Boland ED, Coleman BD, Barnes CP, Simpson DG, Wnek GE, Bowlin $\mathrm{GL}$. Electrospinning polydioxanone for biomedical applications. Acta Biomater. 2005 Jan; 1(1):115-23.

3. Cantwell CP, Pena CS, Gervais DA, Hahn PF, Dawson SL, Mueller PR. Thirty years' experience with balloon dilation of benign postoperative biliary strictures: long-term outcomes. Radiology. 2008 Dec;249(3):1050-7.

4. Conde,LauroMassaudetal.Laparoscopicmanagementofcholecystocolic fistula. ABCD, arq. bras. cir. dig., Dec 2014, vol.27, no.4, p.285-287. ISSN 0102-6720

5. Costamagna G, Endotherapy of postoperative biliary strictures with multiplestents: results aftermorethan 10 years offollow-up. Gastrointest Endosc. 2010 Sep;72(3):551-7.

6. Costamagna G, Long-term results of endoscopic management of postoperative bile duct strictures with increasing numbers of stents. Gastrointest Endosc. 2001 Aug;54(2):162-8.

7. de Santibañes E, Palavecino M, Ardiles V, Pekolj J. Bile duct injuries: managementoflatecomplications. SurgEndosc.2006Nov;20(11):1648-53.

8. Itoi T, Kasuya K, Abe Y, Isayama H. Endoscopic placement of a new short-term biodegradable pancreatic and biliary stent in an animal model: a preliminary feasibility study. J Hepatobiliary Pancreat Sci. 2011 May;18(3):463-7.

9. JaníkV,HorákL,HnaníčekJ,MálekJ,LaaschHU.Biodegradablepolydioxanone stents: a new option for therapy-resistant anastomotic strictures of the colon. Eur Radiol. 2011 Sep;21(9):1956-61.
10. Kasher JA, Corasanti JG, Tarnasky PR, McHenry L, Fogel E, Cunningham J. A multicenter analysis of safety and outcome of removal of a fully covered self-expandable metal stent during ERCP. Gastrointest Endosc. 2011 Jun;73(6):1292-7.

11. Laukkarinen J, Lämsä T, Nordback I, Mikkonen J, Sand J. A nove biodegradable pancreatic stent for human pancreatic applications: a preclinical safety study in a large animal model. Gastrointest Endosc. 2008 Jun;67(7):1106-12.

12. Laukkarinen J, Nordback I, Mikkonen J, Kärkkäinen P, Sand J. A novel biodegradable biliary stent in the endoscopic treatment of cystic-duct leakageaftercholecystectomy.GastrointestEndosc.2007Jun;65(7):1063-8.

13. Laukkarinen J, Sand J, Leppiniemi J, Kellomäki M, Nordback I. A novel technique for hepatico-jejuno-anastomosis for nondilated bile ducts: a purse-string anastomosis with an intra-anastomotic biodegradable biliary stent. Am J Surg. 2010 Jul;200(1):124-30.

14. Laukkarinen JM, Sand JA, Chow P, Juuti H, Kellomäki M, Kärkkäinen P, et al. A novel biodegradable biliary stent in the normal duct hepaticojejunal anastomosis: an 18-month follow-up in a large animal model. J Gastrointest Surg. 2007 Jun;11(6):750-7.

15. Lillemoe KD, Melton GB, Cameron JL, Pitt HA, Campbell KA, Talamini MA, et al. Postoperative bile duct strictures: management and outcome in the 1990s. Ann Surg. 2000 Sep; 232(3):430-41

16. Meng B, Wang J, Zhu N, Meng QY, Cui FZ, Xu YX. Study of biodegradable and self-expandable PLLA helical biliary stent in vivo and in vitro. J Mater Sci Mater Med. 2006 Jul;17(7):611-7.

17. Middleton JC, Tipton AJ. Synthetic biodegradable polymers as medical devices. Medical Plastics and Biomaterials 1998; 3: 30 - 39

18. Misra S, Melton GB, Geschwind JF, VenbruxAC, Cameron JL, Lillemoe KD. Percutaneous management of bile duct strictures and injuries associated with laparoscopic cholecystectomy: a decade of experience. J Am Coll Surg. 2004 Feb;198(2):218-26.

19. Nordback I, Räty S, Laukkarinen J, Järvinen S, Piironen A, Leppiniem $J$, et al. A novel radiopaque biodegradable stent for pancreatobiliary applications--the firsthuman phase I trial in the pancreas. Pancreatology. 2012 May-Jun;12(3):264-71

20. Palermo Mariano, Giménez Mariano, Gagner Michel. Laparoscopic Gastrointestinal Surgery. Novel Techniques, extending thelimits. Editoria AMOLCA. 2015.

21. Pérez Roldán F, González Carro P, Villafáñez García MC, Aoufi Rabih S, Legaz Huidobro ML, Sánchez-Manjavacas Múñoz N, et al Usefulness of biodegradable polydioxanone stents in the treatment of postsurgical colorectal strictures and fistulas. Endoscopy. 2012 Mar;44(3):297-300.

22. PetrtýlJ,BrůhaR, HorákL,ZádorováZ, DosedelJ,LaaschHU.Managementof benignintrahepaticbileductstrictures:initialexperiencewithpolydioxanone biodegradable stents. Endoscopy. 2010;42 Suppl 2:E89-90.

23. Ramos-De la Medina A, Misra S, Leroy AJ, Sarr MG Management of benign biliary strictures by percutaneous interventional radiologic techniques (PIRT). HPB (Oxford). 2008;10(6):428-32.

24. Ray JA, Doddi N, Regula D. Polydioxanone (PDS), a novel monofilament synthetic absorbable suture. Surg Gynecol Obstet 1981; 153: 497 - 507

25. Rejchrt S, Kopacova M, Brozik J, Bures J. Biodegradable stents for the treatmentofbenignstenoses ofthesmallandlargeintestines. Endoscopy. 2011 Oct;43(10):911-7.

26. Repici A, Vleggaar FP, Hassan C, van Boeckel PG, Romeo F, Pagano N et al. Efficacy and safety of biodegradable stents for refractory benign esophageal strictures: the BEST (Biodegradable Esophageal Stent) study. Gastrointest Endosc. 2010 Nov;72(5):927-34.

27. Sabino AM, Gonzales S, Marquez L, Feijoo JL. Study of the hydrolytic degradation of poly- dioxanone PPDX. Polym Degrad Stab 2000; 69 $209-216$

28. Tashiro H, Ogawa T, Itamoto T, Ushitora Y, Tanimoto Y, Oshita A, et al. Bioabsorbable stent material for duct-to-duct biliary reconstruction. J Surg Res. 2009 Jan;151(1):85-8.

29. WinslowER, Fialkowski EA, Linehan DC, HawkinsWG, PicusDD, Strasberg SM. "Sideways": results of repair of biliary injuries using a policy of side-to-side Hepaticojejunostomy. Ann Surg. 2009 Mar;249(3):426-34.

30. Yamamoto K, Yoshioka T, Furuichi K, Sakaguchi H, Anai H, Tanaka T, et al. Experimental study of poly-L-lactic acid biodegradable stents in normal canine bile ducts. Cardiovasc Intervent Radiol. 2011 Jun;34(3):601-8. 